\title{
EDUCAÇÃO AMBIENTAL NO MEIO RURAL: ESTUDO DE PRÁTICAS AMBIENTAIS EM ESCOLAS DE ENSINO FUNDAMENTAL NA I LHA DE SÃO LUÍS
}

\author{
ENVIRONMENTAL EDUCATION IN THE RURAL ENVIRONMENT: STUDY OF \\ ENVIRONMENTAL PRACTICES IN FUNDAMENTAL SCHOOLS IN THE ISLAND OF SÃO \\ LUÍS
}

Georgiana Eurides de Carvalho Marques ${ }^{1}$, Camilla Bezerra Ferreira de Souza ${ }^{2}$, Leandro Coelho Moura ${ }^{3}$

DOI: https://doi.org/10.52719/bjas.v3i1.3962

\section{RESUMO}

A pesquisa objetivou analisar o processo de ensino-aprendizagem da Educação Ambiental em escolas rurais nos Municípios de Paço do Lumiar e São Luís, Maranhão através de jogos lúdicos e análise de percepção de gestores e professores. A pesquisa teve abordagem metodológica exploratória-descritiva, com caráter qualitativo através de observação, análise da percepção ambiental dos alunos, entrevistas e aplicação de questionários, com os discentes, docentes e gestores, aplicação de jogos lúdicos. Professores e gestores apontaram suas dificuldades para atuação como educadores ambientais e à ausência da interdisciplinaridade, formação continuada e incentivos da Secretaria de Educação nas escolas. O desenvolvimento dos jogos ambientais lúdicos possibilitou uma participação efetiva dos estudantes no processo de aprendizagem, desenvolvendo o exercício da cidadania através de atividades reflexivas. Assim, enfatiza-se a importância de um contexto escolar direcionado para o enfoque da educação ambiental, onde além dos problemas ambientais, seja também trabalhada a relação social e cultural que interfere na relação homem e natureza.

Palavras-Chave: Ensino-aprendizagem. Práticas reflexivas. Meio ambiente. Educação ambiental.

\begin{abstract}
\footnotetext{
${ }^{1}$ Instituto Federal de Educação, Ciência e Tecnologia do Maranhão

${ }^{2}$ Instituto Federal de Educação, Ciência e Tecnologia do Maranhão

${ }^{3}$ Instituto Federal de Educação, Ciência e Tecnologia do Maranhão
}

This research analyzed the teaching-learning process of Environmental Education in rural schools in the Municipalities of Paço do Lumiar and São Luís, Maranhão through playful games and analysis of the perception of managers and teachers. The approach the research was exploratory-descriptive with qualitative character through observation, analysis of the students' environmental perception, interviews and application of questionnaires, with students, teachers and managers, application of playful games. Teachers and managers pointed out their 

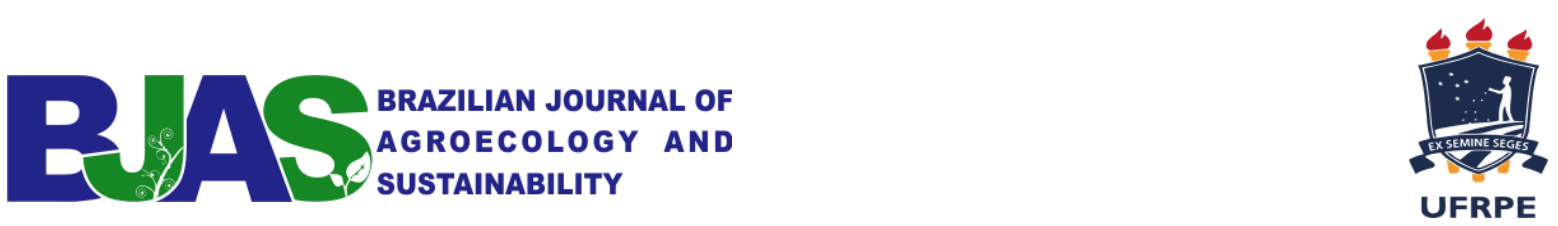

difficulties to act as environmental educators and the absence of interdisciplinarity, continuing education and incentives from the Education Department in schools. The development of playful environmental games enabled students to participate effectively in the learning process, developing the exercise of citizenship through reflective activities. Thus, the importance of a school context focused on the focus of environmental education is emphasized, where in addition to environmental problems, the social and cultural relationship that interferes in the relationship between man and nature is also worked on.

Keywords: Teaching-learning; Reflexive practices; Environment; Environmental education.

\section{INTRODUÇÃO}

A Educação Ambiental (EA) é uma ferramenta que contribui na formação da cidadania do indivíduo, no estudo entre a interação da escola e do ambiente que os alunos e familiares ocupam, caracterizando-a como uma prática pedagógica complexa. Surge com o propósito de despertar a consciência da população global sobre os problemas ambientais consequentes das atividades humanas. Diante disso, uma mudança de atitude se torna necessária para mudar o comportamento frente a esta problemática (Mello, 2017). Apresenta-se como um tema amplo e plural em virtude do cenário atual, no que se refere às adversidades ambientais. A EA insere uma nova visão da relação homem e Meio Ambiente (MA), produzindo uma nova atitude que faz a pessoa se envolver em objetos ambientais. Logo o desafio de um projeto de Educação Ambiental é incentivar as pessoas a se reconhecerem capazes de tomar atitudes (Meirelles \& Santos, 2005).

A zona rural, por muito tempo foi considerada como um lugar rústico no qual não existia acesso à informação. Santos (2018) relata que no período de 1930/40 a escola rural deveria preparar os filhos dos agricultores para continuar na zona rural, a fim de convencer o cidadão a permanecer no meio rural. Na década de 60 e 70 a educação rural entra em contexto desenvolvimentista, com programas educacionais voltados as demandas das regiões e uma replicação de conteúdos aplicados ao ambiente da cidade. Após a década de 1990 a escola rural parou de servir como instrumento formador de mão-de-obra, reprodutor de um modelo educacional excludente e antidemocrático, para começar a organizar um modelo pedagógico que englobasse as dinâmicas rurais, priorizando as particularidades relativas ao aluno através da Educação do Campo (Oliveira \& Gomez, 2014). Logo, a educação do campo deve articular um ensino em que o conteúdo curricular e as metodologias do professor sejam adequadas da agricultura camponesa, que construa conhecimentos, tecnologias na direção do desenvolvimento social e econômico dessa população (Arroyo \& Fernandes, 1999). 

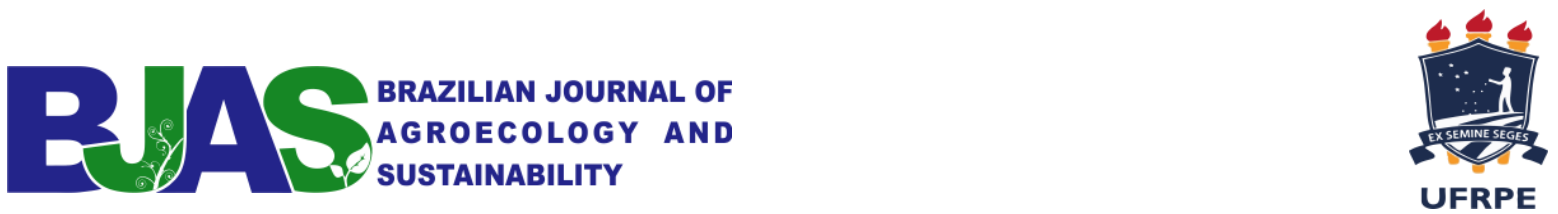

A educação do campo na sua formação prepara as crianças para serem críticas, autônomas para respeitar as regras e direitos tanto dos colegas, quanto das demais pessoas que as rodeiam dentro de sua rotina. Neste sentindo a Educação Ambiental precisa fazer parte desta contextualização e união como um dos saberes universais e contextualizados (Ongaro et al., 2018). A literatura apresenta poucos dados sobre práticas pedagógicas ambientais voltadas a escolas rurais do Maranhão, em que os saberes associados a realidade do campo e suas práticas de ensino estejam alinhadas. Diante desta lacuna, esta pesquisa visou identificar à presença e execução de temas geradores em Educação Ambiental, verificando o quanto a comunidade é ativa dentro da escola, se os problemas recorrentes de atividades agrícolas são levados em conta na formação do plano anual escolar.

Assim, consciente da relevância da prática da Educação Ambiental nas escolas rurais, destacando a necessidade de instrução dos alunos das escolas do campo, visando o reconhecimento das especificidades do ambiente rural esta pesquisa buscou analisar o processo de ensino-aprendizagem da Educação Ambiental em escolas rurais nos Municípios de Paço do Lumiar e São Luís, Maranhão, através da inserção de atividades lúdicas com tema Meio Ambiente na sala de aula, analise da percepção ambiental dos estudantes, professores e gestores.

\section{MATERIAL E MÉTODOS}

\subsection{Caracterização das escolas}

A pesquisa foi desenvolvida em duas escolas rurais localizadas nos municípios de São Luís e Paço do Lumiar localizadas na Ilha de São Luís, Maranhão no período de 2017 a 2019.

A primeira escola foi a Unidade de Educação Básica Alfredo Silva, com a participação de alunos do $6^{\circ}, 7^{\circ}, 8^{\circ}$ e $9^{\circ}$ ano do Ensino Fundamental. A escola está localizada na comunidade de Iguaíba, zona rural do município de Paço do Lumiar. A escola é municipal, compõe o quadro da Secretaria Municipal de Educação (SEMED) do Paço Lumiar. A escola oferta à comunidade às series finais ( $\left(6^{\circ}\right.$ a $9^{\circ}$ ano) com cerca de 400 alunos, Educação de Jovens e Adultos com cerca de 56 alunos e Educação Especial com cerca de 19 alunos (Censo Escolar, 2018).

A segunda escola foi a Unidade de Educação Básica Uruati localizada no bairro da Ananandiba (Matinha) no município de São Luís. A escola é municipal integra a Secretaria Municipal de Educação de São Luís. A escola oferta à comunidade os anos iniciais $\left(1^{\circ}\right.$ ao $5^{\circ}$ ano) com cerca de 446 alunos matriculados, anos finais ( $6^{\circ}$ ao $9^{\circ}$ ano) com cerca de 287 alunos matriculados, Educação de Jovens e Adultos com cerca de 80 alunos e Educação Especial com cerca de 22 alunos (Censo Escolar, 2018). 


\section{R/AS}

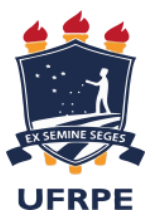

\subsection{Método}

A pesquisa caracterizou-se como exploratório-descritiva, com uso de ferramentas para a padronização de coleta de dados, através da investigação e a observação direta extensiva, com utilização de questionários, formulários, transcrição de relatos de opiniões e ações metodológicas como descritas em Lakatos e Marconi (2010).

No primeiro momento foi realizada a observação nas escolas campo, posteriormente foram aplicados questionários semiestruturados com perguntas subjetivas e objetivas para levantamento dos dados junto a informantes-chave locais (gestores, professores e alunos), enfocando aspectos relacionados às práticas pedagógicas na escola, conscientização dos alunos sobre o Meio Ambiente e as influências do meio, além da caracterização do corpo docente (formação profissional e prática docente). O segundo momento foi a intervenção em sala de aula com aplicação de jogos lúdicos aos estudantes sobre temas transversais ligados a Meio Ambiente, através das práticas ambientais.

Todos os participantes receberam o Termo de Consentimento Livre Esclarecido (TCLE) e a pesquisa está aportada no Parecer no 978.585 do Comitê de Ética do Centro Universitário do Maranhão (CEUMA).

As análises aconteceram a partir das transcrições de narrativas, questionários, pesquisa de campo, empírica e bibliográfica.

\subsection{Práticas Ambientais}

\section{Construção do Mapa Mental}

Para compreender o nível de percepção do que é Meio Ambiente dos alunos, a primeira etapa consistiu em aplicar uma ferramenta chamada de Mapa Mental, no qual os alunos construíram desenhos sobre suas percepções a respeito do Meio Ambiente. O desenho tem sido empregado como técnica metodológica em crianças e pré-adolescentes para compreender a percepção e concepções relacionadas ao Meio Ambiente, antecedendo quaisquer prática na Educação Ambiental (Reigada \& Tozoni- Reis, 2004).

\section{Aplicação de Atividades Lúdicas}

Após as análises dos mapas mentais, foi identificado o déficit dos alunos acerca do conhecimento sobre o tema Meio Ambiente, sendo realizada a terceira etapa, com a construção de cinco jogos lúdicos para a sensibilização ambiental e fixação dos conceitos e ações pautados 

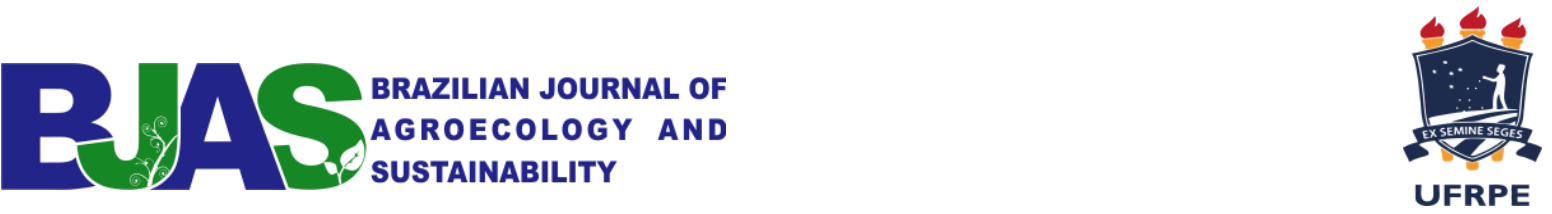

na Educação Ambiental. Segundo Rizzo (1997), para melhor desenvolvimento do aprendizado do indivíduo, as atividades lúdicas são ótimos recursos do educador, incentivando a criatividade, consciência crítica e reflexiva. Segundo Cunha (2012) os jogos estão no cotidiano da sociedade, seja por prazer, diversão, competição ou como ferramenta de aprendizagem, sendo assim, o ato de jogar é uma prática do homem.

\section{Proposta de jogo 1 Ludotal}

Jogo construído baseado no tabuleiro de ludo, com quatro peões de cores diferentes, por isso os alunos são divididos na mesma quantidade em equipes, o objetivo do jogo é chegar no meio da sua área, designada pela cor do seu peão (Figura 1).

Figura 1

Proposta de jogo: Jogo Ludotal

(a) Tabuleiro do Ludotal

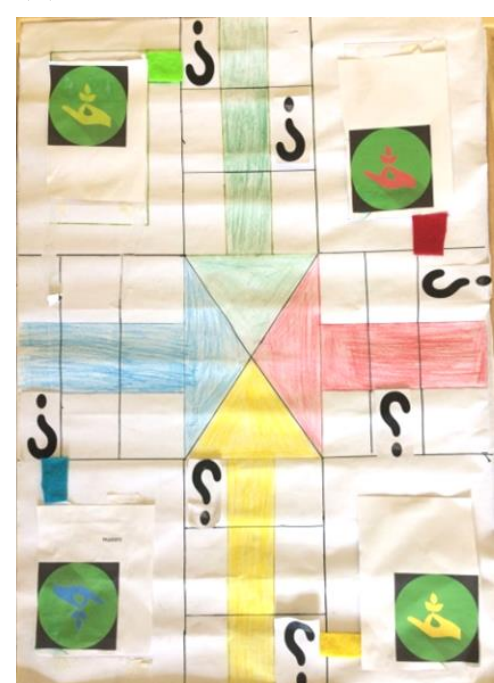

Fonte: Autor (2019) (b) Cartas do jogo

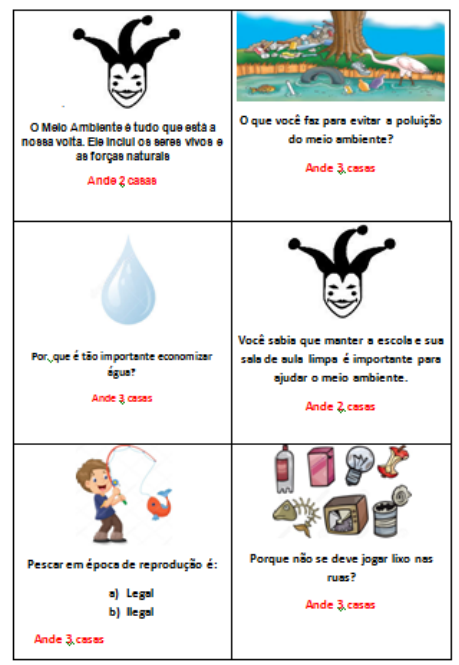

Ao cair nas casas os alunos escolhem uma carta que tem uma pergunta, ao responderem certo podem andar as casas designadas na carta, se for completada por outros grupos, estes ganham o direito de andar uma casa. No tabuleiro existem casas coringas, informativos importantes acerca da Educação Ambiental, como energia solar, eólica, economia de combustíveis fosseis e etc.

Proposta de jogo 2: Jogo da memória

O propósito do jogo foi que os alunos encontrassem os pares iguais de elementos que estão na natureza, ao encontrar o mediador explicava que aquela imagem também estava na natureza e o porquê (Figura 2). 

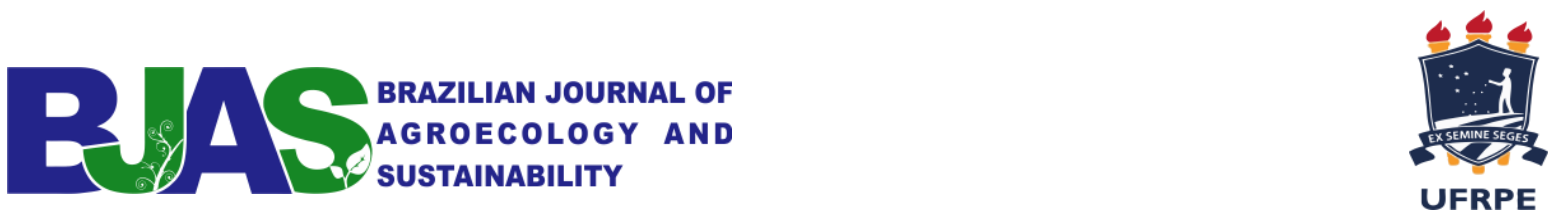

Figura 2

Proposta de jogo 2: Cartas jogo da memória

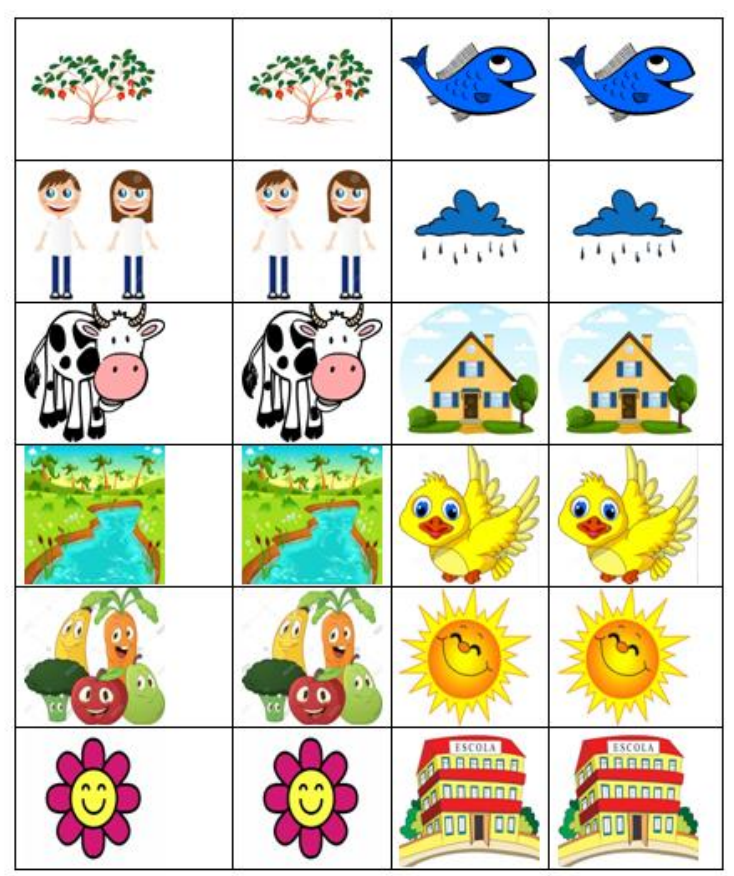

Fonte: Autor (2017)

Proposta de jogo 3: Forca Ambiental

Os discentes tinham que adivinhar quais palavras estavam no quadro (Figura 3), para que o boneco não fosse enforcado, acontecia através da quantidade de letras dispostas, a sensibilização acontecia durante o jogo através das dicas do mediador.

Figura 3

Proposta de jogo 3: Jogo da forca e suas peças

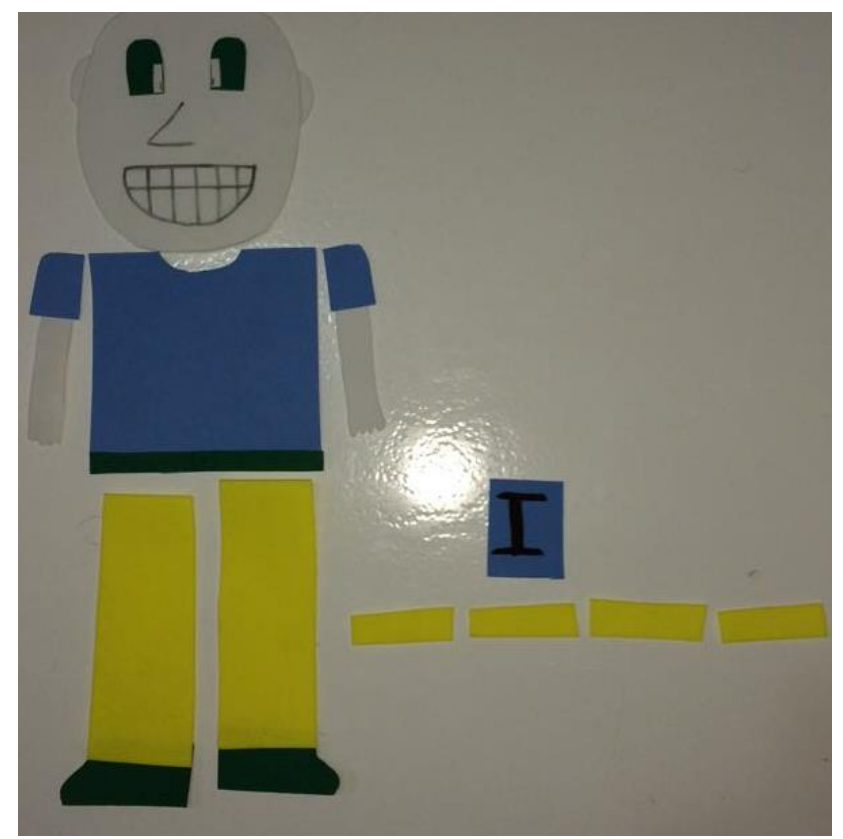

Fonte: Autor (2017) 
Proposta de jogo 4: Jogo a mímica

O jogo (Figura 4) visava conscientizar e sensibilizar a turma acerca de temas geradores das questões ambientais, ao se movimentarem para fazer a mímica, os alunos refletiam o que pensavam sobre o tema, de certa forma sensibilizando os seus colegas à medida que tentavam adivinhar o que eles estavam fazendo, pois conseguiam observar as atitudes boas ou ruins.

Figura 4

Proposta de jogo 4: Cartas do jogo da mímica

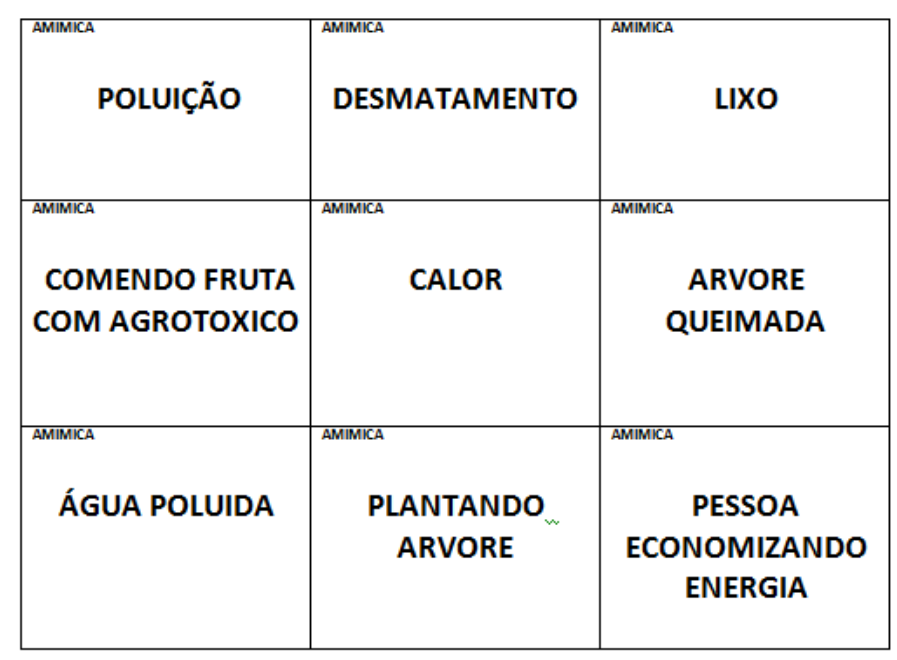

Fonte: Autor (2017)

Proposta de jogo 5: Cada um no seu quadrado

No último jogo (Figura 5) aplicado, a finalidade foi testar se os alunos adquiriram o conhecimento geral acerca da Educação Ambiental e fixar as atitudes adequadas, de forma lúdica. Então cada grupo colocava as cartas do que é legal e o que não é legal para o Meio Ambiente em seu respectivo lugar na cartolina, sempre perguntando por que o aluno está colocando aquela carta naquele quadrado.

Figura 5

Proposta de jogo 5: Cada um no seu quadrado

(a) Cartas aplicadas no jogo Cada um no seu quadrado (b) Quadro do jogo 


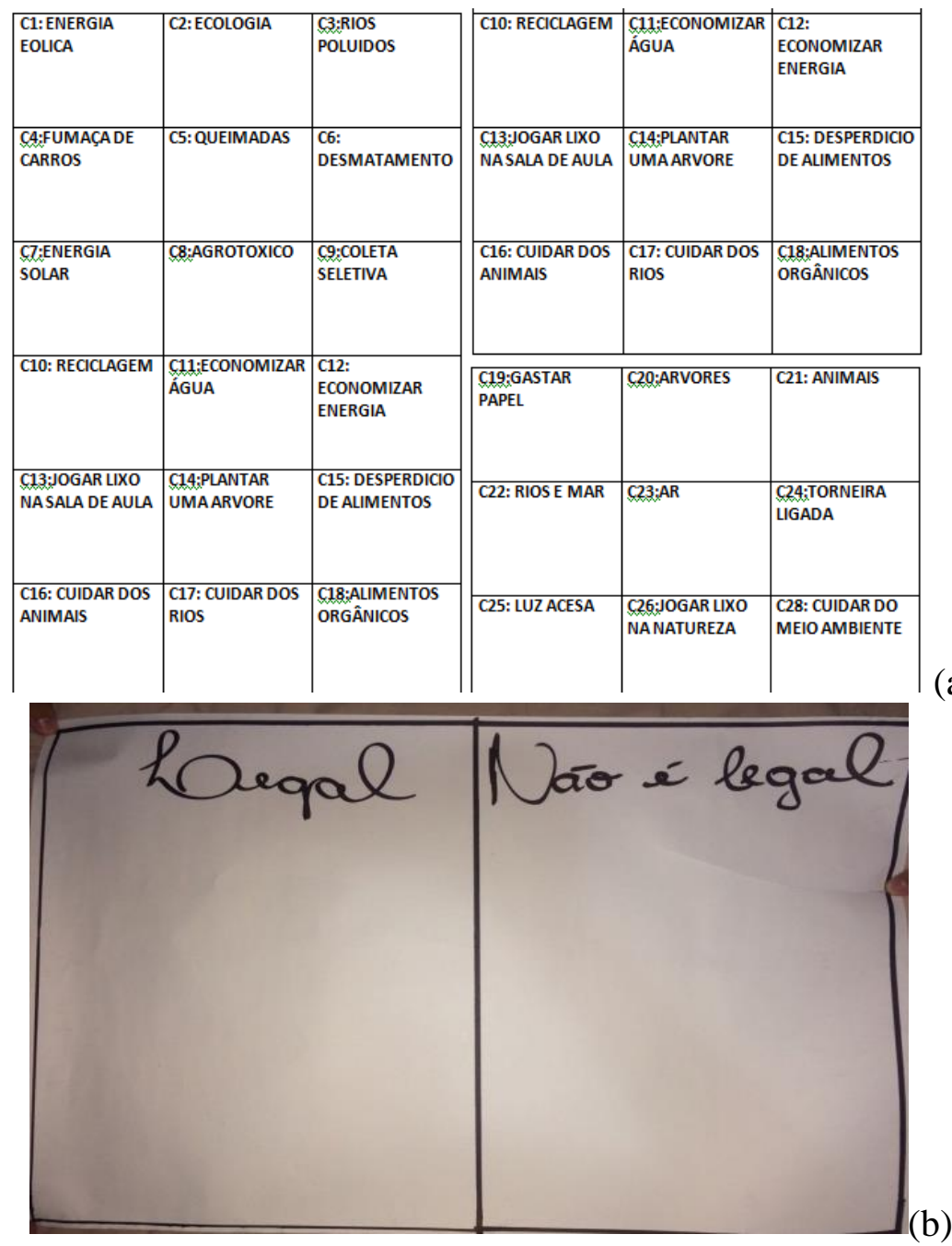

Fonte: Autor (2017)

\section{RESULTADOS E DISCUSSÃO}

\subsection{Unidade de Educação Básica Alfredo Silva Mapa Mental}

Ao analisar a percepção dos alunos sobre os elementos do Meio Ambiente nos desenhos do Mapa Mental verificou-se que associavam com sua casa e vegetação nativa que está no em torno de onde vivem como coqueiro, aceroleira, juçareira, mangueira, jambeiro, cajueiro, bananeira dentre outros (Figura 6). Este fato refere-se à abundância de árvores na comunidade e, principalmente, porque a principal fonte de renda da região é a agricultura, logo na escola quando são tratadas as questões ambientais, estas se voltam para a vegetalidade.

O ser humano tem uma atração natural pelos aspectos físicos paisagísticos do Meio Ambiente, denominado de topofilia e definido como todos os laços afetivos dos seres humanos com o Meio Ambiente material (Tuan, 1980). Assim o agricultor tem uma percepção do que é Meio Ambiente diferente de uma pessoa inserida no meio urbano. Além disso, Hoeffel e Fadini 
(2007) relatam que as percepções são formadas por experimentação, a partir das circunstâncias históricas e culturais, sem certo ou errado.

Figura 6

Desenhos realizados por alunos da U E B Alfredo Silva

(a) Desenho aluno $7^{\mathrm{a}} \mathrm{A}$

(c) Desenho aluno $9^{\mathrm{a}} \mathrm{B}$

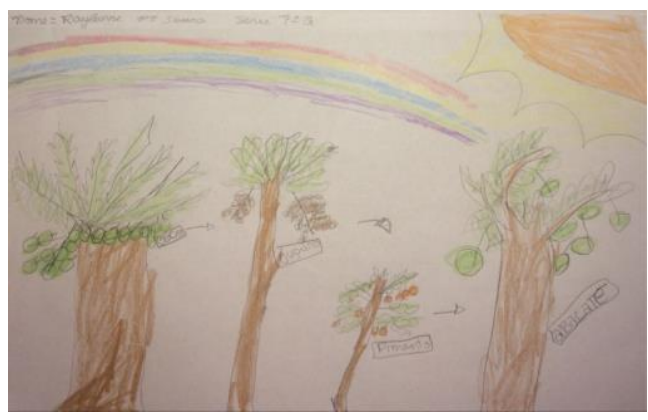

(b) Desenho aluno $8^{\mathrm{a}} \mathrm{A}$

(d) Desenho aluno $6^{\mathrm{a}} \mathrm{B}$

(a)
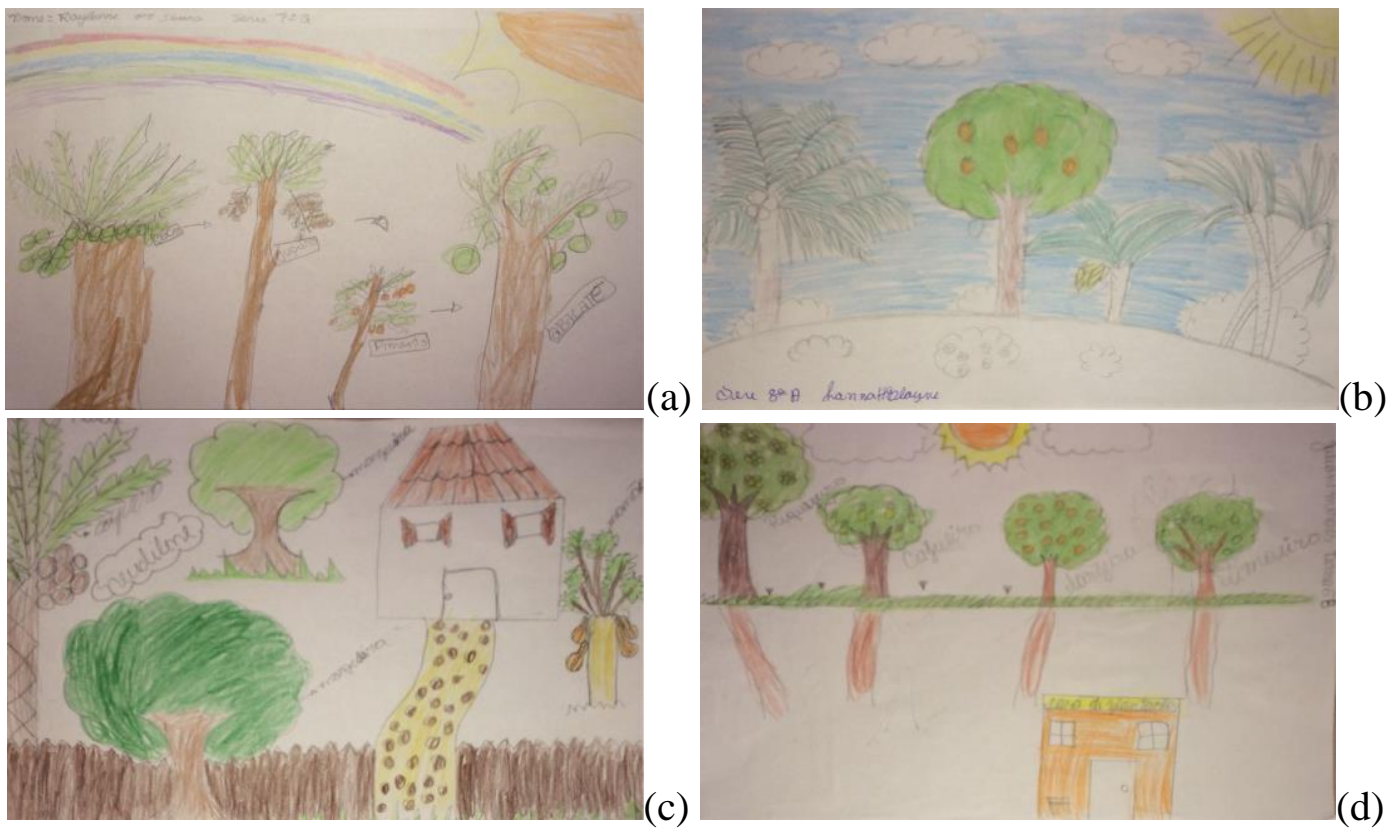

Fonte: Autor (2017)

\section{Alunos e a Educação Ambiental}

Participaram da pesquisa 91 alunos de diferentes anos, sendo $29 \%$ do $6^{\circ}, 23 \%$ entre as $7^{\circ}, 26 \% 8^{\circ}$ e $23 \%$ do $9^{\circ}$ ano do Ensino Fundamental. A faixa etária predominante dos indivíduos participantes da pesquisa foi de 11 a 13 anos, sendo $62 \%$ da população estudada, e apenas $38 \%$ entre de 14 a 16 anos.

Os resultados em relação fonte do conhecimento dos alunos sobre o Meio Ambiente mostrou que apenas $10 \%$ adquirem por livros, $19 \%$ pela internet, $31 \%$ pela TV e $40 \%$ estudam a disciplina na escola, esse dado determina o papel importante da escola para construção do conhecimento acerca do Meio Ambiente. Segundo Lucena e Soares (2012), apesar da escola não ser a única encarregada pela educação, no entanto é a mais importante e oficial instituição para cumprir este papel.

Segundo os PCNs (1998), os meios de comunicação, o rádio, imprensa e especialmente a televisão, correspondem como fonte de dados sobre o Meio Ambiente para a multidão, tendo 


\section{BRAZILIAN JOURNAL OF}

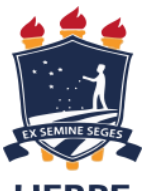

uma função de incentivadoras nos debates que geram modificações e soluções dos problemas regionais.

Quando perguntado aos alunos sobre se o Meio Ambiente é importante, 95\% responderam que SIM, demonstrando a importância dos estudos do Meio Ambiente, assim como, da sua inserção em disciplinas de educação ambiental e das discussões sobre questões ambientais em sala de aula. Por se tratar de uma comunidade rural, essa ideia é primordial, pois a natureza é a fonte de renda dos moradores, colocando em evidência a valorização do meio que estão inseridos. Neste respeito, a EA trabalha com a apreciação dos elementos que envolvem o ser humano no seu ambiente de trabalho, doméstico e comunitário. Segundo Tuan (1980), a região onde o indivíduo reside influência na sua visão, interpretação e valorização sobre o ambiente.

Nos PCNs o Meio Ambiente é tratado como tema transversal e interdisciplinar, com o objetivo de contribuir para a formação de cidadãos conscientes, aptos para decidirem e atuarem na realidade socioambiental de um modo comprometido com a vida, com o bem estar de cada um e da sociedade, local e global (Parâmetros Curriculares Nacionais, 1998). Apesar da interdisciplinaridade da Educação Ambiental, foi observado que o tema está ligado as disciplinas do eixo Ciências da Natureza (Brasil, 2010). A maioria dos alunos identificaram Ciências como a disciplina responsável por informá-los sobre o Meio Ambiente, totalizando 55\% dos entrevistados, $38 \%$ dos alunos apontaram Geografia como disciplina informativa sobre o referido tema. Estes dados também comprovam as análises dos mapas mentais, em que o estudante identifica como Meio Ambiente apenas a vegetação e sua casa, pois nestas disciplinas são trabalhados dentro da sala de aula, os biomas, relevo, solo e vegetação. Outros $2 \%$ assinalaram Português, 3\% História e 2\% Inglês como mediadoras dos conhecimentos a respeito da EA. A dificuldade das outras disciplinas em abordar o tema Meio Ambiente, podem ser reflexos da ausência das práticas docentes em trabalhar a multi e transdiciplinariedade nas escolas. A inter, multi e transdisciplinariedade configura-se como a inserção dessas bases na formação educacional como uma nova perspectiva formativa, que possui uma visão do sujeito global, da valorização da diversidade, da ruptura com modelos que enclausuram o conhecimento (Sousa \& Pinho, 2017)

Além da vegetalidade demonstrada nos mapas mentais, nos questionários surgiu um novo elemento de interesse dos alunos, que são os rios (Figura 7). A comunidade do Iguaiba tem uma morfologia natural com rios e mangues, onde encontra-se o rio Paciência e o Porto do Iguaiba, que representa uma fonte de peixes e crustáceos para os moradores da região. Dentre as respostas mais observadas, destaca-se as dos alunos A, B e C: 
Figura 7

Respostas dos alunos à pergunta "Como você acha que as pessoas podem colaborar para melhorar elou conservar o ambiente em que vivem?" (a)Aluno A, (b)Aluno B, (c) Aluno C.

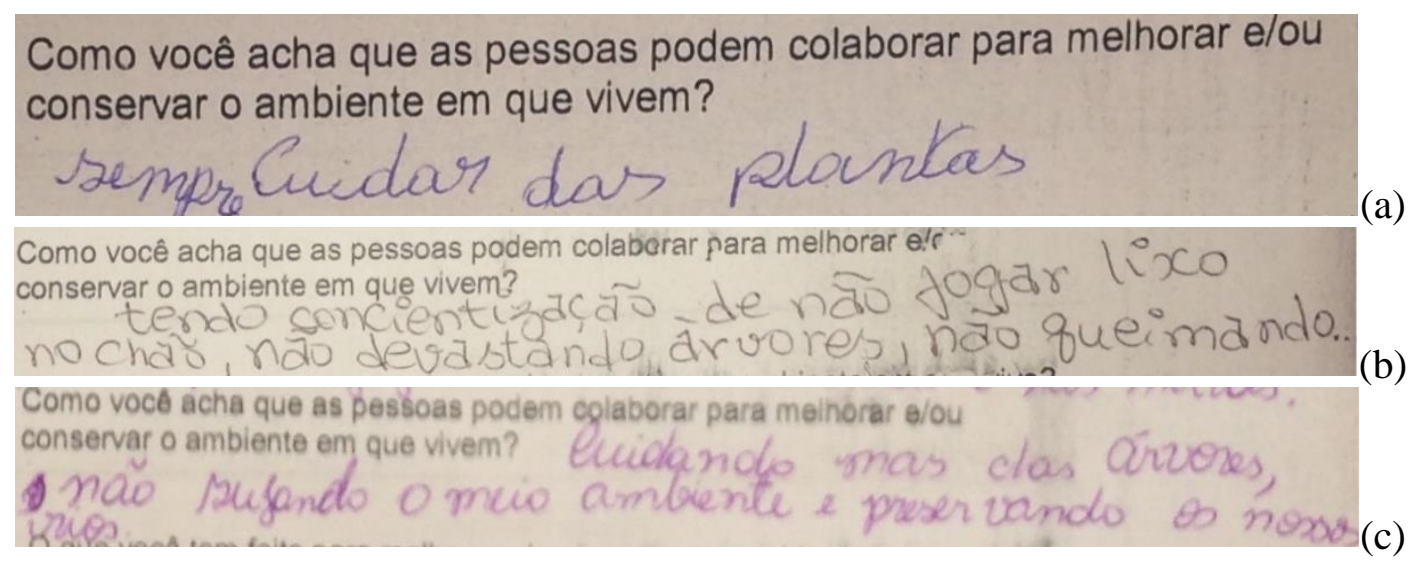

Em relação a pergunta do questionário sobre o que estão fazendo para melhorar e/ou conservar o ambiente em que vivem (Figura 8), a percepção dos estudantes refere-se a suas ações de plantio e cuidado com as árvores e plantas. Posteriormente, os alunos também relataram sobre o descarte do lixo, em virtude de ser uma problemática da comunidade, pois não possuem coleta regular de lixo, como também foi citado pelos gestores da escola. Apesar desta preocupação nenhum dos alunos citaram a reciclagem como uma ação direcionada à conservação e manutenção do ambiente, e o desperdício de água.

Figura 8

Respostas dos alunos sobre "O que você tem feito para melhorar elou conservar o ambiente em que vive?" (a)Aluno A, (b)Aluno B, (c) Aluno $C$.

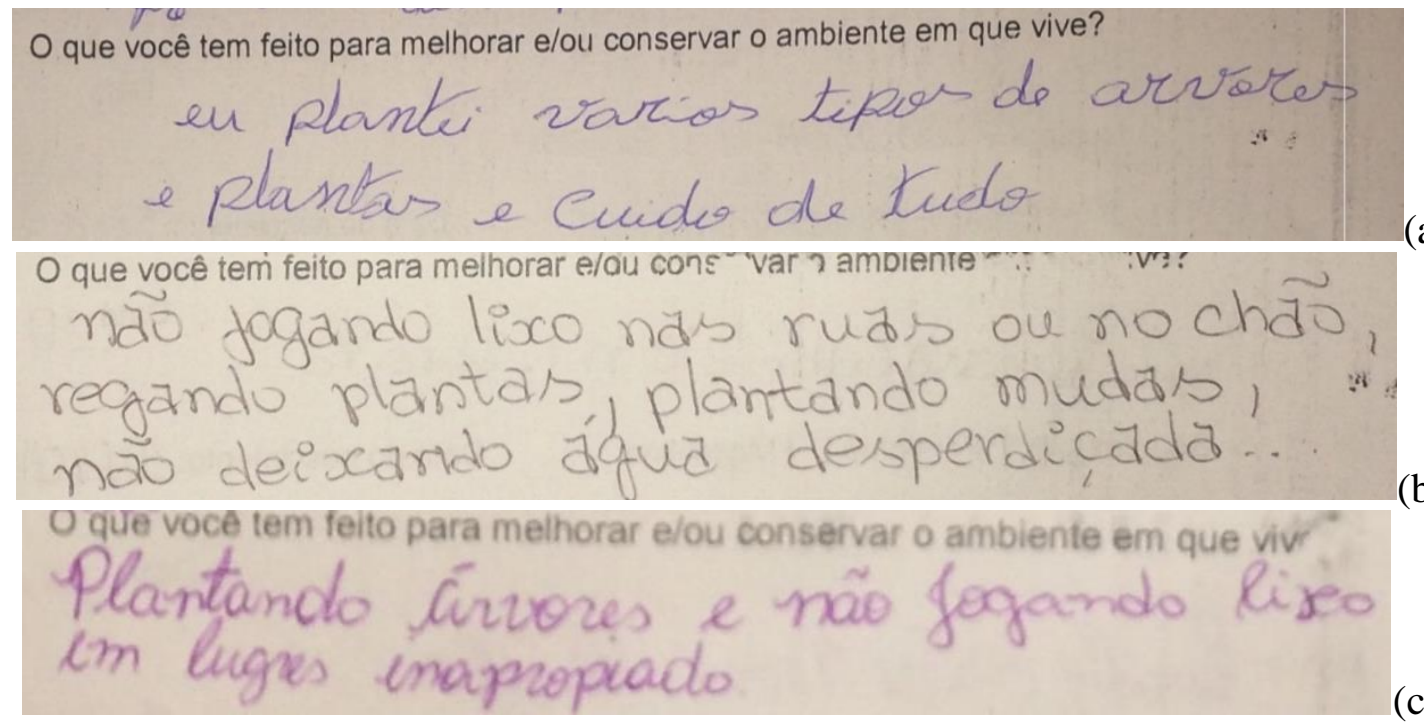




\section{R/AS:}

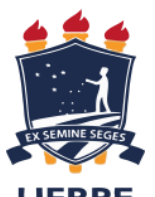

Participaram da pesquisa, um total de 10 professores de diferentes disciplinas (Português, Matemática, Geografia, Inglês, Educação Física, Ciências, Geografia, História e Filosofia).

Em relação a questão do questionamento se os professores já desenvolveram alguma atividade voltada para à Educação Ambiental na sua disciplina, 57\% responderam que Sim e 43\% Não, mantendo uma margem muito pequena entre as respostas. Apesar da interdisciplinaridade da Educação Ambiental, observa-se que boa parte dos professores ainda não consegue aborda - lá em sua disciplina. A interdisciplinaridade da EA permite sua inserção nos diferentes campos educacionais, o que inclui os planejamentos curriculares e organização do ensino (Isaia, 2001).

Em relação como a Educação Ambiental está incluída na organização escolar, a diretora (A) e a diretora adjunta (B) afirmaram:

Diretora A: "Em projetos"

Adjunta B: "Projeto Arborização onde todos os professores tiveram participação, Gincana em que teve uma das provas de coleta de materiais e Agricultura, que o professor de Geografia levou os alunos em hortas para explicar sobre vegetação e solo".

Para as diretoras a EA é vista com pontual, inserida em projetos e atividades isoladas. No que tange a EA é um desafio mudar esta concepção de ensino de forma isolada porque exige mudanças de planejamentos e de gestão. Para Fragoso e Nascimento (2018) é um desafio fazer a EA de forma transversal, pois constitui em uma nova forma de pensar a educação, com a integração da formação, do conhecimento, do desenvolvimento social do aluno, por fim que proporcione uma educação básica sólida, ou seja, a formação integral do educando.

Quando perguntado sobre "Você se considera preparado para atuar como educador ambiental?", todos os entrevistados responderam que NÃO, esse resultado é justificado pela pergunta "Você já fez algum curso voltado a pratica da Educação Ambiental", em que 71\% responderam que NÃO, as gestoras também afirmaram que não estão preparadas. Essa falta de conhecimento teórico sobre a EA reflete diretamente na falta de preparo, consequentemente de abordagens das questões ambientais dentro da sala de aula. Os docentes precisam ser formados para analisar o ambiente que a escola está inserida com propostas pedagógicas que sejam realizadas na prática, focadas na sensibilização e conscientização do indivíduo sobre as questões ambientais, propiciando modificações no comportamento e auxiliando os alunos na construção dos saberes da educação ambiental (Mello, 2017). 

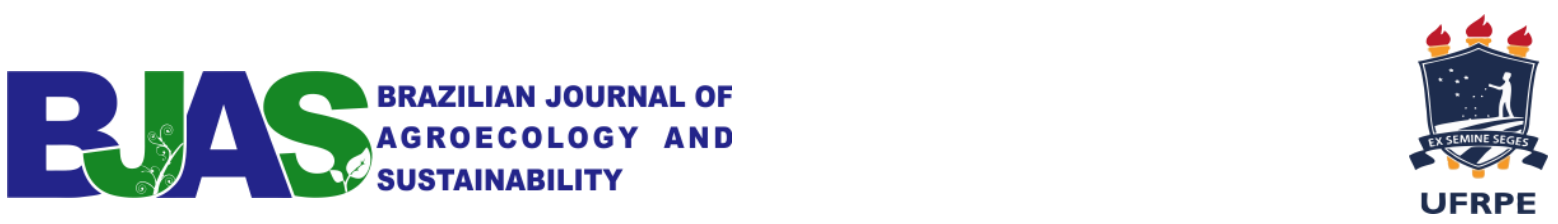

$\mathrm{Na}$ perspectiva da formação de professores em EA diversas literaturas citadas por Martins e Schnetzler (2018), indicam que são realizadas apenas ações pontuais para formação docente e que trazem abordagens naturalistas e/ou antropocêntricas que não são suficientes para a incorporação da dimensão ambiental no currículo de formação de professores, nem para a institucionalização da EA no Brasil.

No processo de qualificação dos educadores é necessário moldar um conteúdo pedagógico voltado para a política da Educação Ambiental, envolvendo práticas pedagógicas, noções sobre legislação ambiental, fundamentos da gestão ambiental e provocando uma autonomia do pensamento do educador, ao construir uma perspectiva critica reflexiva (Neves \& Festozo, 2011).

Os professores acham que o incentivo dos gestores e a SEMED é parcial no que se refere ao incentivo nas práticas e sensibilização ambientais dentro da sala de aula. No questionário quando perguntados sob esse incentivo afirmaram o seguinte:

\section{Professor A: "Sinto que isso está iniciando agora" \\ Professor B: "Na medida do possivel" \\ Projeto C: "Sim, com o projeto de arborização" \\ Professor D: "Não. Há na verdade a preocupação com a presença e as horas dadas. Não há nada especifico."}

Esse incentivo também demanda da importância que os gestores e a SEMED, embutem na Educação Ambiental. Quando a diretora foi questionada "Há interesse na inserção da temática educação ambiental no Projeto Político Pedagógico da escola?”

Diretora A: "Sim, inclusive vai ser inserido, nosso PPP está em construção. Todos os projetos voltados para as questões ambientais já aplicados na escola serão incluídos".

Atividades Lúdicas

Ludotal

Com uso deste método foi trabalhado alguns temas que trouxeram reflexões. No caso se alunos comeriam fruta com agrotóxico, o aluno (A) respondeu "Não, tem veneno. Denotando que o entendimento sobre os riscos do agrotóxico, mesmo que superficial. Quando questionados “Como preservar os rios"?" Responderam “Não jogando lixo nele”, o mediador ao observar que a resposta estava incompleta, acrescentou dizendo que não se pode cortar a mata ciliar ou as arvores que ficam ao redor do rio, para manter as margens, e preservá-lo, um aluno completou dizendo que lá eram as arvores dos manguezais. Quando indagados O que é reciclagem?”, o discente respondeu "É quando pegamos garrafas plásticas e transformamos em outra coisa". 

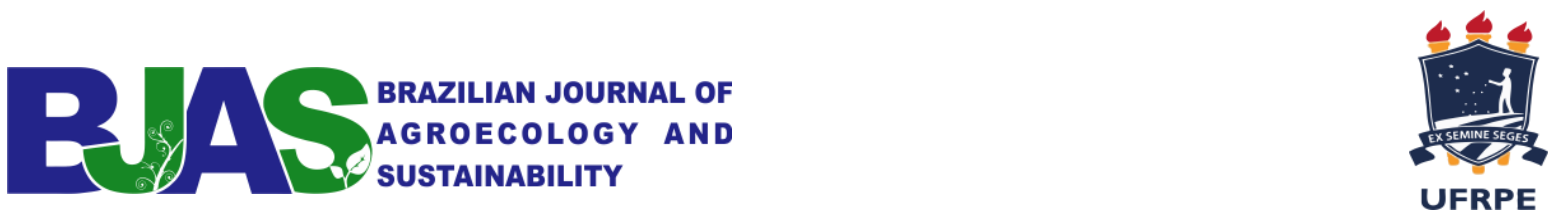

Observou-se que os alunos apresentavam conhecimentos sobre as condições de preservação e conservação do Meio Ambiente, de forma superficial e não formal, o que necessita de um trabalho mais extensivo para ampliar o entendimento deles a respeito da Educação Ambiental, no sentido de transformá-los também em sensibilizadores ambientais, permitindo o exercício do seu papel de cidadão politizado dentro de uma sociedade. Por isso, a função do mediador mostrou-se importante, pois construiu durante a execução do jogo conceitos de preservação junto com o educando, sensibilizando ao decorrer da intervenção. Segundo Tristão (2004) não se trata de aprender uma quantidade enorme de coisas, mas sim de pensar de outra maneira sobre os problemas que se apresentam no cotidiano, estabelecer vínculos e conexões para tornar significativo o processo de aprendizagem.

Ao comunicar as informações citadas nas cartas coringas, primeiro indagava-se sobre o conhecimento a respeito do que estava na carta, como por exemplo, "Vocês já ouviram falar em energia eólica?", a turma respondeu que sim, um aluno disse "aquilo que parece um ventilador, energia do vento”. As cartas coringas auxiliaram na mediação de conceitos que os alunos não tinham tanto domínio, como sustentabilidade, ecologia, aquecimento global, economia de água, energia e combustíveis fósseis. No momento que saiu a carta "Você sabia que usar bicicleta ajuda o Meio Ambiente?” Muitos responderam que não, em seguida foi explicado que os meios de transportes como carros e ônibus são abastecidos com combustíveis fosseis explorados do Meio Ambiente, então ao andar de bicicleta eles estavam ajudando a conservar o ambiente em que vivem, comentaram "Ainda bem que venho para escola de bicicleta".

\section{Jogo da memória}

Ao decorrer da aplicação deste jogo verificou que os alunos começaram a correlacionar outros elementos do Meio Ambiente, tendo outra visão do seu redor, idealizando que está inserido constantemente no Meio Ambiente. O uso de jogos motiva os alunos no processo de aprendizagem, segundo Vygotsky (1988) a utilização de jogos como cruzadinhas, dominó, o jogo da memória e entre outros, torna o processo de aprendizagem mais interessante e divertido para os alunos.

\section{Jogo da mímica}

Observou-se que de forma divertida os alunos conseguiram captar a essência do jogo, sem dificuldades em adivinhar o que estava sendo representado por seus colegas. Mesmo não acertando exatamente como estava na carta, como por exemplo, ao fazerem a mimica 
"Comendo uma fruta com agrotóxico", primeiro falaram "Comendo fruta envenenada”, ao informar que a resposta era parecida, logo eles conseguiram dizer que "Comendo comida com agrotóxico.".

Facilmente os alunos conseguiram relacionar a sua realidade, com jogos contextualizados com o ambiente em que vivem, após associar e compreender as informações, ele se torna apto a entender o quão é importante para o Meio Ambiente e a comunidade, através de suas ações pessoais e coletivas (Breda \& Picanço, 2011).

\section{Forca Ambiental}

Esse jogo é igual a alguns jogos que os alunos já estão habituados, portanto foi de fácil aplicação e resultado. Os grupos escolhiam a carta com a palavra para adivinharem, então no quadro o mediador colocava as barras das letras para indicar quantas tinham na palavra. Durante o jogo o mediador dava dicas como quando saiu a carta "Coleta seletiva", a dica foi "O que devemos fazer com o nosso lixo doméstico", mediante as dicas era simples para os estudantes determinassem qual palavra estava no quadro. Para Souza et al., (2015) o uso de jogos lúdicos com temas ambientais contribui para a promoção de determinadas práticas em sala de aula promovendo a interação dialógica, além de auxiliar no processo ensino-aprendizagem.

\section{Cada um no seu quadrado}

Esse foi o último jogo aplicado em sala de aula a fim de verificar a aprendizagem dos temas abordados em sala de aula pelos alunos. Nenhuma equipe errou em qual quadrado deveria estar à carta, conseguiram justificar de forma satisfatória quando questionado o motivo de estar colocando naquele quadrado. Quando a mediadora perguntou "por que gastar papel não é legal? ", um aluno respondeu "Porque derruba árvores", outra fala interessante é quando questionados o porquê de torneira ligada não é legal, responderam "não ajuda a preservar os rios".

Dessa forma observou-se que o uso de jogos lúdicos no ensino na escola rural trouxe benefícios no processo de ensino-aprendizagem, favorecendo a interação, a competividade, a motivação, a participação, tornando a aula mais atraente aos alunos e transformadora para o professor motivador. 


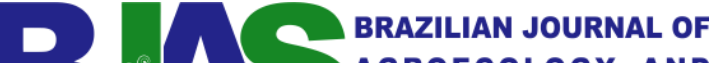 \\ AGROECOLOGY AND \\ SUSTAINABILITY}

\subsection{Unidade Básica Escolar Uruati}

\section{Mapa Mental}

As ilustrações de acordo com a Figura 9 mostraram que os discentes identificavam como Meio Ambiente a sua casa e a vegetação nativa como coqueiros, bananeiras e mangueiras que estão no em torno de onde vivem. Com base nos desenhos solicitados observou-se a grande importância das árvores na comunidade uma vez que na escola as questões ambientais são voltadas a vegetalidade. Esta característica já tinha sido vista na unidade escolar anterior estudada. De acordo com Pereira et al., (2018) a percepção ambiental está intimamente ligada aos processos históricos e socioculturais de um determinado grupo, logo por ser um ambiente rural, a visão do alunado vai representar seus quintais e seu cotidiano.

Figura 9

Desenhos feitos por alunos do U E B Uruati, Matinha - São Luís (MA)
(a) Desenho Aluno3 ${ }^{\mathrm{a}} \mathrm{A}$
(b) Desenho aluno $3^{\mathrm{a} B}$
(c) Desenho aluno $3^{\mathrm{a}} \mathrm{C}$
(d) Desenho aluno $3^{\mathrm{a}} \mathrm{D}$
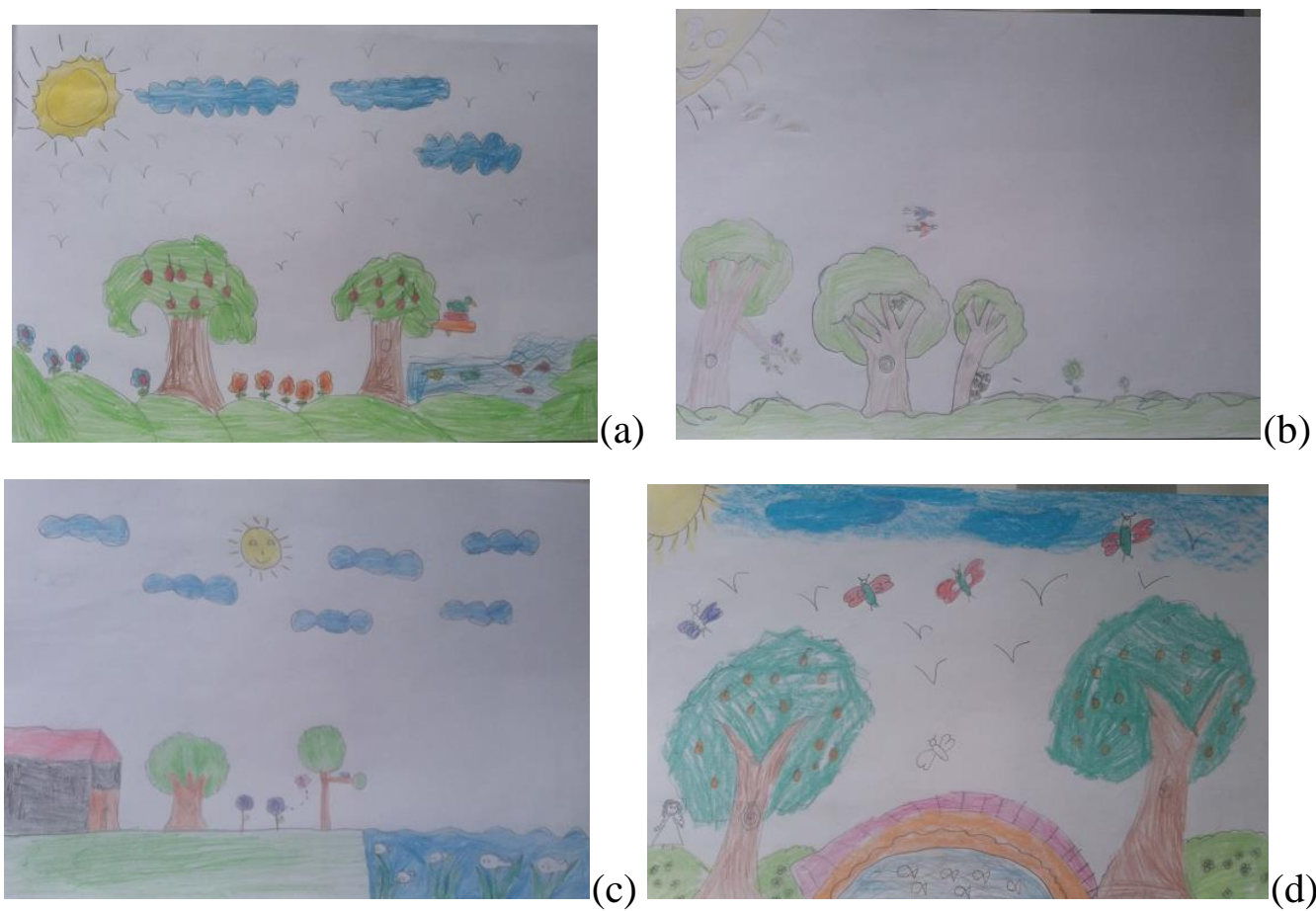

Fonte: Autor (2018)

\section{Alunos e a Educação Ambiental}

O quantitativo de alunos matriculados que participaram da pesquisa foram 39 distribuídos no terceiro ano, estes eram alunos remanescentes que obtiveram um resultado não 

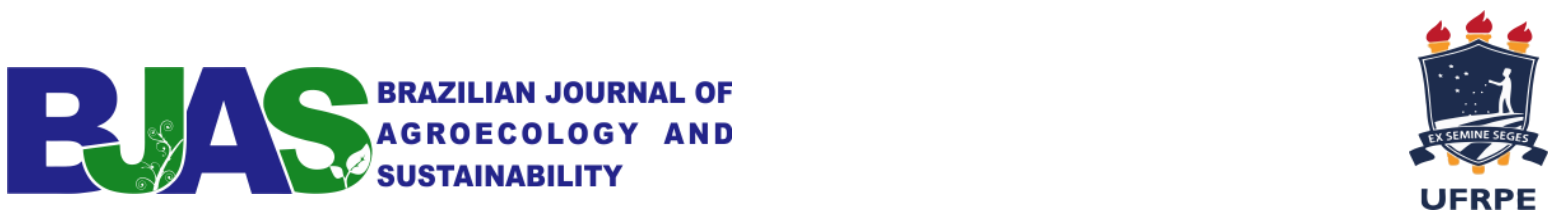

satisfatório durante o ano letivo e eram os únicos que ainda frequentavam as aulas. A faixa etária dos indivíduos participantes da pesquisa foi de 8 a 9 anos.

Os resultados com relação ao conhecimento dos alunos sobre o Meio Ambiente mostraram que apenas $14 \%$ adquirem por livros, $4 \%$ pela internet, $6 \%$ pela TV e $66 \%$ obtêm em disciplina na escola. Mostra o papel da escola fundamental para mediação do saber e de extrema importância para construção do conhecimento do aluno acerca do Meio Ambiente. Segundo Medeiros et al., (2011) as questões ambientais estão presentes no cotidiano da sociedade, com importância da sua presença nos níveis dos processos educativos e em especial nos anos iniciais da escolarização, pois é mais fácil conscientizar as crianças sobre as questões ambientais do que os adultos.

Quando foi perguntado ao entrevistado “O Meio Ambiente é importante pra você?" 95\% responderam que sim, o que retrata sua relevância para os alunos, pois através dos estudos sobre Meio Ambiente a sua percepção acrescenta-se princípios e atitudes sobre as principais discussões ambientais. A escola deve trazer a educação ambiental partindo dos conhecimentos prévios dos alunos, que permite aos alunos analisarem a natureza de acordo com suas práticas sociais, além de construir uma análise crítica que poderá contribuir para as mudanças de valores sobre o cuidado com o Meio Ambiente (Bortolon \& Mendes, 2014).

Observar-se que a maioria dos alunos identificaram a disciplina de Ciências como a responsável por informá-los sobre o Meio Ambiente, totalizando 52\% dos alunos entrevistados, $30 \%$ dos alunos apontaram Geografia como disciplina informativa do Meio Ambiente. Com esse levantamento deixa claro que as análises dos mapas mentais, em que o aluno identifica como Meio Ambiente apenas a vegetação, sua casa e rios, pois é nessas matérias em que são concentrados conteúdos acerca dos biomas de forma geral. Outros 9\% assinalaram como resposta Português e 8\% História, como conciliadores dos conhecimentos a respeito da Educação Ambiental. Estes dados acompanharam os da outra escola pesquisada, mostrando a dificuldade das práticas da inter - transdisciplinariedade. Neste sentindo, vislumbras-se a importância da Educação Ambiental como preceitos da interdisciplinariedade, na qual deve fazer parte de todas as disciplinas a fim de contribuir para a formação integral do aluno. Para Conrado e Silva (2018) na prática da interdisciplinaridade o uso metodologias para que o ensino se torne mais dinâmico, apontando para a solução de problemas, ou seja, o processo educativo interdisciplinar deve estar conectado a atitudes que façam parte do cotidiano dos alunos/seres humanos que estão em formação.

A Educação Ambiental e a Interdisciplinaridade através de suas apostas metodológicas buscam informar e estimular a percepção dos educadores ambientais, profissionais e da 

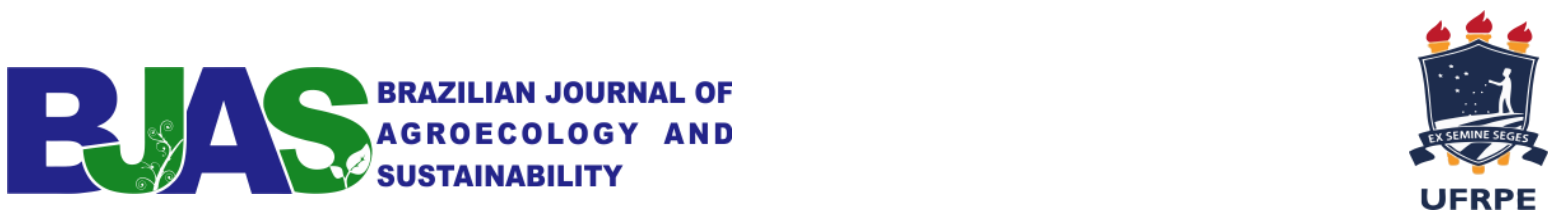

população, de modo a sensibilizá-los para participar de ações, num exercício pleno de cidadania, que possam encontrar soluções sustentáveis que assegurem a manutenção e elevação da qualidade de vida e da qualidade que o ser humano tem de se integrar (Coimbra, 2005).

Vale realçar que após ser feito a comparação entre os questionários e os mapas mentais, pode-se perceber que a maioria dos alunos associam que o Meio Ambiente está relacionado à presença de arvores, rios, lagos e as casas. Com isso salienta-se que após serem indagados se realmente eles estão preocupados como o Meio Ambiente onde vivem, destacaram-se as respostas dos seguintes entrevistados A, B e C (Figura 9).

Figura 9

Principais formas de colaborar para melhorar elou conservar o ambiente em que vivem

(a)Aluno A, (b) Aluno B, (c) Aluno C.

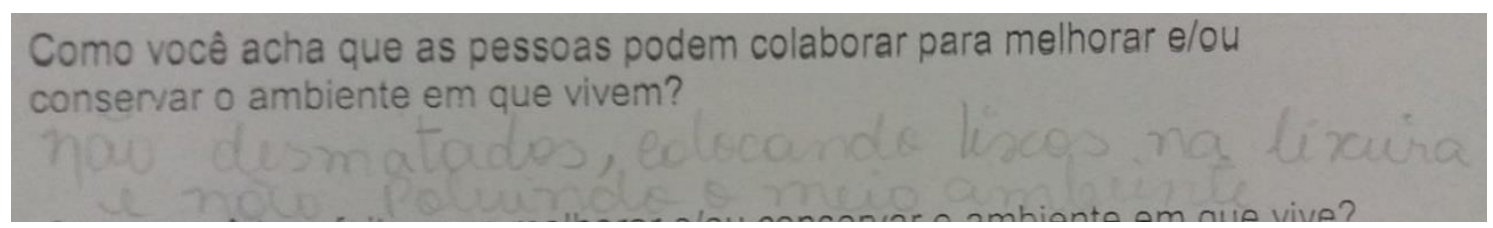

(a)

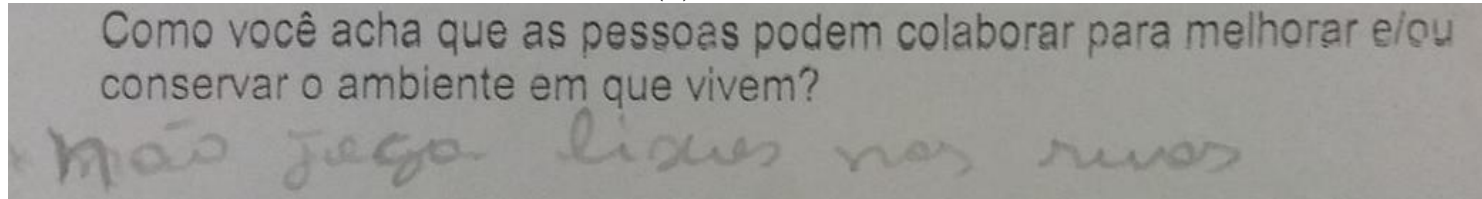

(b)

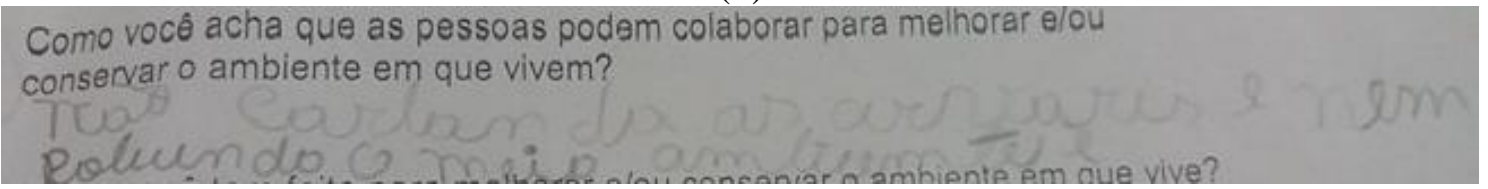

(c)

Fonte: Autor (2018)

Ao ser questionados sobre o que estão fazendo para melhorar e/ou conservar o ambiente em que vivem, a percepção dos alunos é semelhante à da outra escola estudada, pois as suas ações primeiramente se preocupam com o descarte do lixo, sendo uma problemática da maioria das comunidades, principalmente da zona rural, no sentido de não possuírem uma coleta regular de lixo (Figura 10). E, logo em seguida vem o problema das queimadas, que é algo que assola as redondezas em que as escolas estão localizadas.

Figura 10

O que se tem feito para melhorar elou conservar o ambiente em que se vive

(a) Aluno A, (b) Aluno B, (c) Aluno C. 


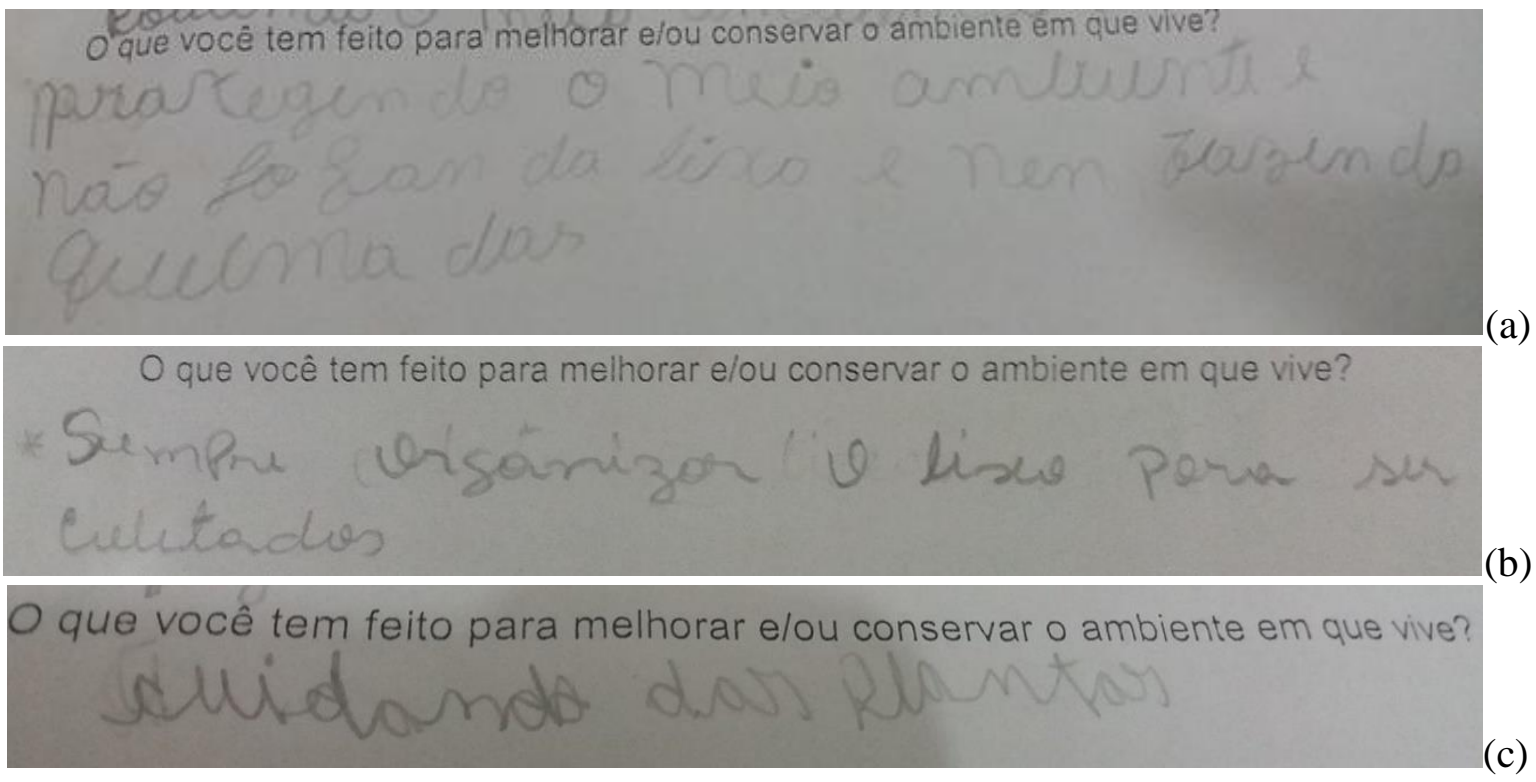

Fonte: Autor (2018)

Essa pergunta foi de muita relevância para avaliar a conscientização ambiental que os alunos têm sobre o ambiente em que vivem. Quando se pensa em favorecer a comunidade que se vive ou onde se frequenta, é importante superar os tormentos com a busca de soluções para dentro de seu alcance. As respostas dos discentes, refletem situações vivenciadas pelos estudantes.

\section{Corpo Docente e Gestores}

Em relação ao quadro de professores participaram da pesquisa apenas 3 professoras do Ensino Fundamental e a gestora da escola. Considerando que, as docentes compõem o quadro dos anos iniciais, estas lecionam todas as disciplinas.

Quando questionadas se já desenvolveram alguma atividade voltada para a prática da Educação Ambiental. A decisão foi unânime, todas responderam que SIM e uma apresentou expressando exemplos como a compostagem, aproveitamento de cascas de frutas e legumes, plantação de mudas dentre outras atividades. No entanto, uma das entrevistadas não se sente preparada para o exercício de atuar como Educador Ambiental. A tarefa de ensinar EA não é fácil, pois a abordagem interdisciplinar para os educadores ambientais permite a compreensão mais globalizada do ambiente, trabalhar a interação em equilíbrio dos seres humanos com a natureza (Coimbra, 2005).

Quando as professoras foram questionadas se a SEMED incentivar as práticas de sensibilização ambiental dentro da sala de aula, apresentaram o seguinte posicionamento:

Professor A: "A gestão possibilita sim, quando agrega projetos como ECOA e IFMA. Mas poderia haver um maior suporte, para melhores resultados”. 
Professor B: "Sim. A gestora da escola incentiva trabalhos que mudem a realidade da escola e a SEMED sempre promove cursos e atividades pertinentes ao tema".

Professor C: "Não, todas as iniciativas são feitas pelos professores".

Os resultados evidenciam a importância da inserção da Educação Ambiental para os alunos dentro da escola rural, para valorização do espaço em que vivem e seu papel político na sociedade. O conhecimento parcial dos alunos com relação ao Meio Ambiente e suas questões, também depende da formação adequada dos professores para que possam construir uma percepção mais ampla da Educação Ambiental em sala de aula. Neste sentido, Medina (2002) argumenta que a Educação Ambiental torna-se um instrumento importante para a consolidação dos novos modelos de desenvolvimento sustentável que consideram a justiça social, a melhoria da qualidade de vida das populações envolvidas, em que o processo participativo é realizado com o indivíduo e a comunidade na construção de valores sociais e éticos, em que adquirem conhecimento, atitudes, competências e habilidades voltadas para o cumprimento do direito a um ambiente ecologicamente equilibrado em prol do bem comum das gerações presentes e futuras.

Vale ressaltar que a escola possui um espaço "árvore dos sonhos" destinado para que se apresentem as sugestões de melhorias na escola, onde todos podem colar seus desejos, sendo um espaço democrático e compartilhado pelos gestores, alunos e professores (Figura 11). Nesta árvore encontram-se citações de melhorias, como por exemplo: sala de informática, jardim, mais professores, horta, bebedouros, banheiros adequados dentre outros. 
Figura 11

Árvore dos Sonhos que descreve as sugestões de como se trabalhar com o Meio Ambiente na escola UEB Uruati

Fonte: Autor (2018)

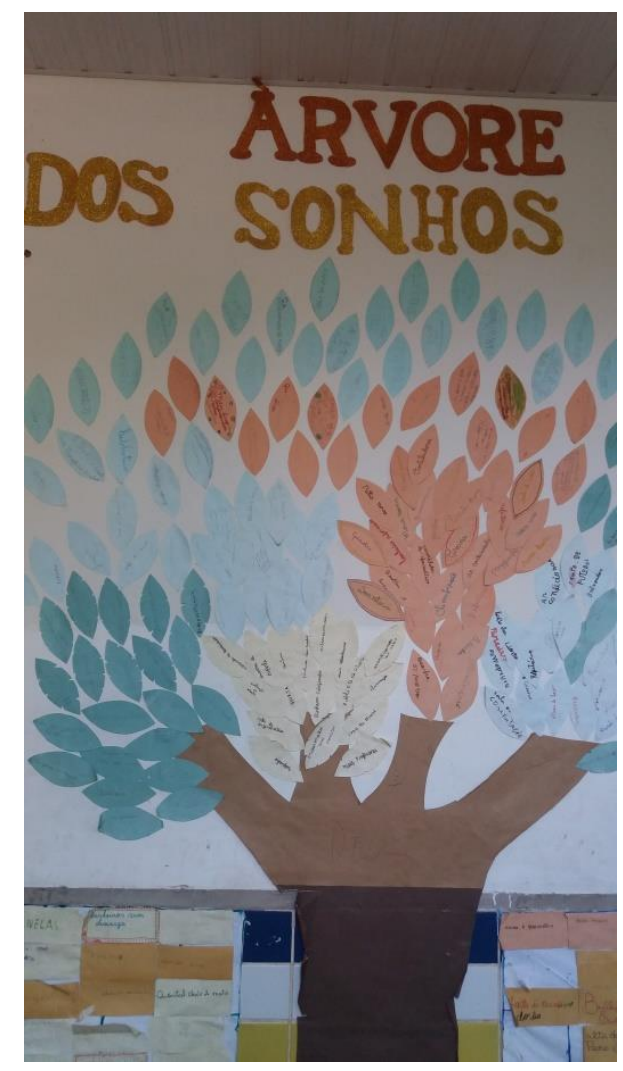

Atividades Lúdicas

Mapa Mental

Os jogos apresentados neste trabalho discutem o espaço vivido pelos discentes. Trabalham com alguns conceitos fundamentais para a interpretação e leitura de Mapas Mentais, como a memorização, a interpretação de feições e noções de localização e escala, entre outras. Quando se apropriam do conteúdo das imagens, os alunos são levados a discutir mudanças e problemas ambientais, equilíbrio de sistemas e outros temas importantes na prática da EA. Desta forma, os jogos aqui discutidos podem contribuir para o processo de valorização de uma consciência ambiental nos alunos e para a transformação de seus comportamentos, pois permitirem uma interação com o sujeito e objeto, o que vem de encontro com as propostas dos PCNs:

A perspectiva ambiental deve remeter os alunos à reflexão sobre os problemas que afetam a sua vida, a de sua comunidade, a de seu país e a do planeta. Para que essas 
informações os sensibilizem e provoquem o início de um processo de mudança de comportamento, é preciso que o aprendizado seja significativo, isto é, os alunos possam estabelecer ligações entre o que aprendem e a sua realidade cotidiana, e o que já conhecem (Brasil, 2001).

\section{Atividades Lúdicas}

Ludodal

As questões perguntadas aos alunos foram semelhantes ao da Escola Alfredo Silva, apesar da faixa etária ser menor, os alunos mostraram conhecimentos sobre os temas, com apresentação de várias indagações (Figura 12).

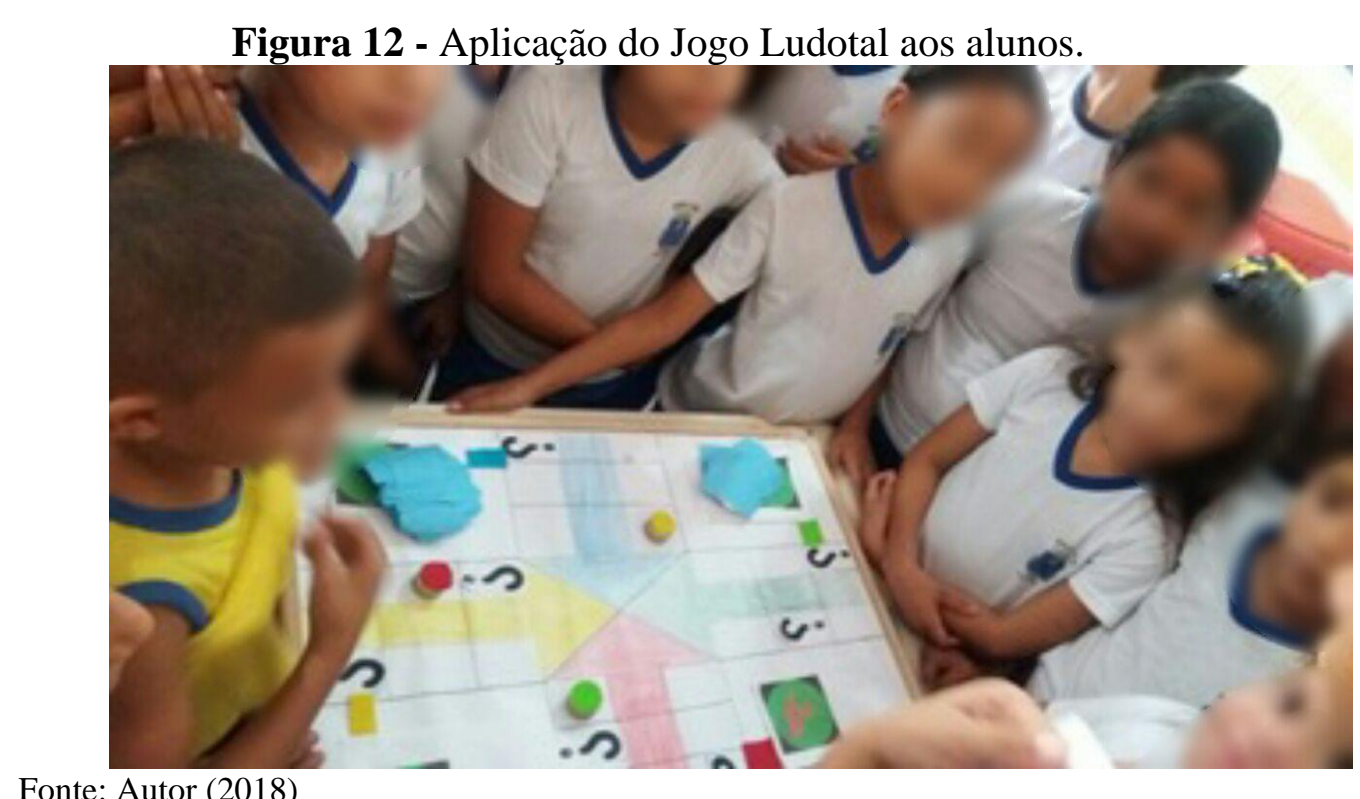

\section{Forca Ambiental}

Neste jogo o mediador instruiu com dicas como quando saiu a carta "Derrubada das árvores", a dica foi "O que não devemos fazer com elas", mediante as dicas era simples para os alunos determinarem qual palavra estava no quadro e assim concluíssem a atividade. Com isso, conclui-se que os alunos conseguiam correlacionar tranquilamente as dicas com as palavras. Vale destacar também que essa é uma atividade simples e de bastante importância para que seja aplicada em sala de aula com propósito de entusiasmar os alunos em relação ao Meio Ambiente. Siqueira e Antunes (2013) trazem afirmações sobre o uso de jogos como instrumento que desperta a curiosidade e interesse dos estudantes, motivando-os em sala de aula, gerando competição e cooperação que favorecem a aprendizagem. 

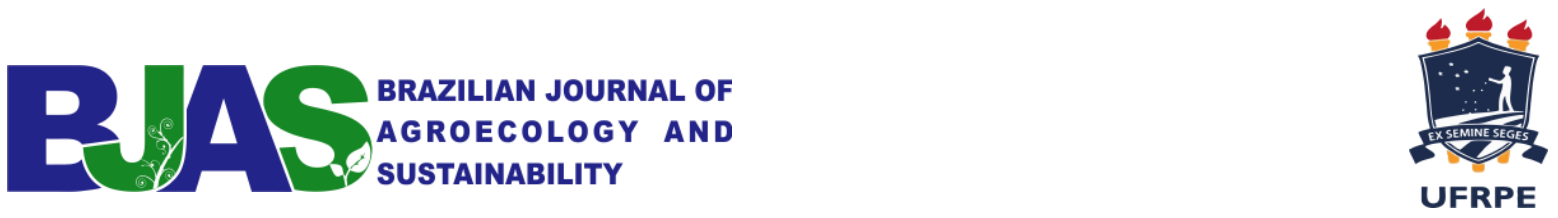

A mímica

Essa atividade que consistiu nos movimentos e ações dos alunos durante a apresentação possibilitou um divertimento dos participantes em suas equipes. Em cartas de papel escreveramse algumas problemáticas e situações sobre a Educação Ambiental relacionado a pontos positivos e negativos. Facilmente os alunos conseguiram relacionar a sua realidade, com jogos contextualizados com o ambiente em que vivem. Após associar e compreender as informações, ele se torna apto a entender o quão é importante para o Meio Ambiente e a comunidade as ações pessoais e coletivas (Breda \& Picanço, 2011). Novamente notou-se que o uso do jogo didático contribui para o desenvolvimento de habilidades cognitivas dos educandos. Santana et al., (2019) destacam que para o uso de jogos didáticos o professor tem um papel fundamental, com sua participação ativa no processo, pois este instrumento não é simplesmente aplicado, mas sim, pensado com um planejamento até os objetivos e conteúdo específicos para atingir seu fim.

\section{Jogo da memória}

Este jogo foi produto das análises dos Mapas Mentais, ao constatar que os alunos tinham uma percepção do Meio Ambiente apenas direcionada à vegetação local, produziu-se o jogo da memória com elementos que não foram desenhados como animais, a escola, chuva, humanos, rios dentre outros. Barboza et al., (2016) relatou que em Mapas Mentais sobre temas de Educação Ambiental é comum reconhecer vários elementos naturais e artificiais, prevalecendo os naturais. No decorrer da aplicação deste jogo verificou-se que os alunos começaram a correlacionar outros elementos do Meio Ambiente interligando os seus locais do cotidiano, $\operatorname{logo}$ mostraram uma noção sobre os elementos da natureza.

\section{CONSIDERAÇÕES FINAIS}

Os resultados obtidos por meio do Mapa Mental, questionários e da aplicação dos jogos, apontam uma concepção naturalista, que conhecem superficialmente das ações positivas e negativas as quais o Meio Ambiente sofre, esse saber dos alunos está interligado com o fato de residirem na zona rural. As noções dos educandos foram superficiais, mas mostram a importância dos educadores das escolas como mediador da aprendizagem.

Para os professores e gestores mostrou-se a dificuldade de serem educadores ambientais devido à ausência da interdisciplinaridade, formação continuada e incentivos das Secretarias Municipais de Educação. Observou-se como um grande desafio da escola rural cumprir o seu papel como educador ambiental, em virtude do rompimento com a educação tradicional. 

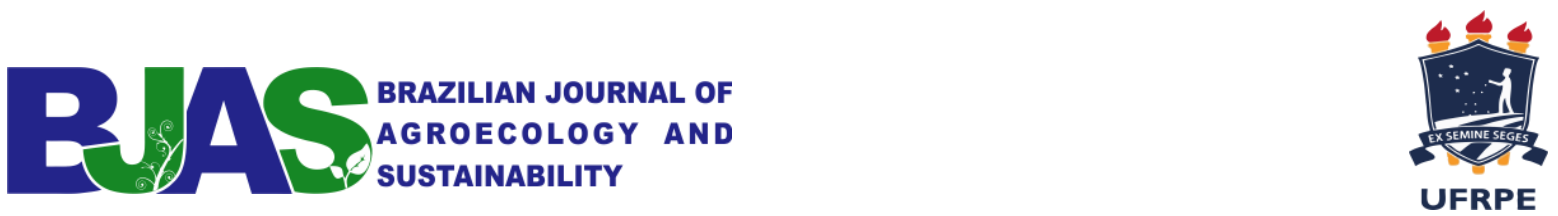

O desenvolvimento dos jogos ambientais lúdicos possibilitou uma participação efetiva dos estudantes no processo de aprendizagem, desenvolvendo o exercício da cidadania através de atividades reflexivas, contribuindo para auxiliar na educação formal e não formal, através da sensibilização do indivíduo e da integração no processo de ação e reação.

Neste contexto pode-se concluir que ambas as escolas envolvidas na pesquisa apresentaram sua percepção ambiental referente Educação Ambiental e um amplo conhecimento sobre temas importantes relacionados ao Meio Ambiente. Neste sentido enfatizase a importância de um contexto escolar direcionado para o enfoque sobre o Meio Ambiente e Educação Ambiental, onde além dos problemas ambientais, seja também trabalhada a relação social e cultural que interfere na relação homem e natureza.

\section{REFERÊNCIAS}

Arroyo, M. G., \& Fernandes, B. M. A. (1999). Educação básica e o movimento social do campo. Brasília, DF: Articulação Nacional Por uma Educação Básica do Campo.

Barboza, L. A. S., Conceição, G. dos S., \& Brasil, D. do S. B. (2016). Percepção ambiental dos alunos do $6^{\circ}$ e do $9^{\circ}$ anos de uma escola pública municipal de Redenção, Estado do Pará, Brasil. Rev Pan-amaz Saude, 4(7),11-20.

Bortolon, B., \& Mendes, M. S. S. (2014). A importância da educação ambiental para o alcance da sustentabilidade. Revista eletrônica de iniciação científica, 5(1),118-136.

Brasil. (1998). A implantação da educação ambiental no Brasil. Brasília, DF.

Brasil. (2010). Ministério da Educação (MEC). Secretaria de Educação Básica (SEB). Diretrizes Curriculares Nacionais para a Educação Infantil. Brasília, DF: $\mathrm{MEC} / \mathrm{SEB}$.

Brasil. (2001). Parâmetros em ação: Meio Ambiente na escola: guia do formador (p. 167-242). Brasília, DF: MEC/SEF

Breda, T. V., \& Picanço, J. de L. (2011). A educação ambiental a partir de jogos: aprendendo de forma prazerosa e espontânea. Anais do Simpósio de Educação Ambiental e Transdisciplinaridade, Goiânia, GO, Brasil, 2.

Censo Escolar. (2018). QEDUC. Recuperado em mar. de 2020, de, https://www.qedu.org.br/escola/26544-ueb-ueb-ens-fund-uruati/censo-escolar.

Coimbra, A. de S. (2005). Interdisciplinaridade e educação ambiental: integrando seus princípios necessários. Rev. eletrônica Mestr. Educação Ambiental, 14, 1-7.

Conrado, L. M. N., \& Silva, V. H. da. (2017). Educação ambiental e interdisciplinaridade: um diálogo conceitua. Revista Gestão \& Sustentabilidade Ambiental, 6(3), 651-665. 

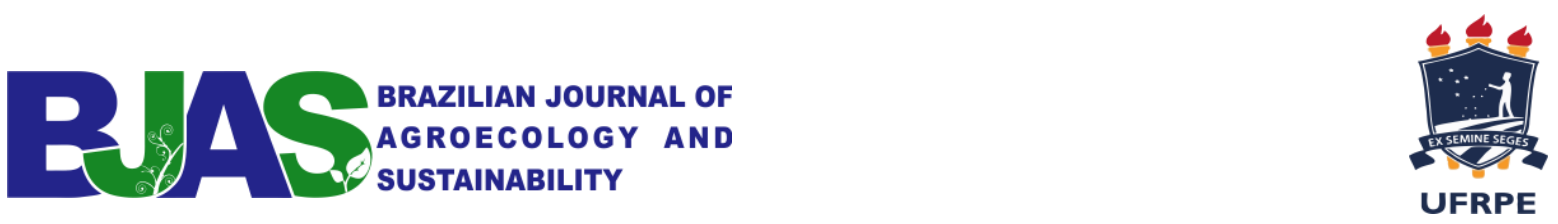

Cunha, M. B. (2012). Jogos no ensino da química: considerações teóricas para sua utilização em sala de aula. Química nova na escola, 34,92-98.

Fragoso, E., \& Nascimento, E. C. M. (2018). A educação ambiental no ensino e na prática escolar da escola estadual cândido mariano - Aquidauana/MS. Revista de Educação Ambiental, 23(1), 161-184.

Hoeffel, J. L., \& Fadini, A. A. B. (2007). Percepção ambiental. In L. F. Ferraro Jr. (Org.). Encontros e caminhos (p. 255-262). Brasília, DF: MMA.

Isaia, E. M. B. (2001). Reflexões e práticas para desenvolver educação ambiental na escola. Santa Maria: UNIFRA.

Lakatos, E. M., \& Marconi, M. de A. (2010). Fundamentos de metodologia científica (7a ed.). São Paulo: ATLAS.

Lucena, V. B., \& Soares, Z. T. (2012). A função da escola a defesa do Meio Ambiente. Revista Universitária, 2(2).

Meirelles, M. de S., \& Santos, M. T. (2005). Educação ambiental uma construção participativa (2a ed.). São Paulo.

Martins, J. P. de A., \& Schnetzler, R. P. (2018). Formação de professores em educação ambiental crítica centrada na investigação-ação e na parceria colaborativa. Ciência $e$ Educação, 24(3), 581-598.

Medeiros, A. B. de, Mendonça, M. J. da S. L., Sousa, G. L. de, \& Oliveira, I. P. de. (2011). A Importância da educação ambiental na escola nas séries iniciais. Revista Faculdade Montes Belos, 4(1), 1-17.

Medina, N. M. (2002). Formação de multiplicadores para educação ambiental. Petrópolis: Vozes.

Mello, L. G. de. (2017). Importância da educação ambiental no ambiente escolar. EcoDebate.

Neves, J. P., \& Festozo, M. B. (2011). Problematizando a formação de professores educadores ambientais. Anais do Encontro "Pesquisa em Educação Ambiental" A Pesquisa em Educação Ambiental e a Pós-Graduação no Brasil, Ribeirão Preto, São Pulo, Brasil, 6.

Ongaro, M. D., Schirmer, G. J., \& Meurer, A. C. (2018). Uma análise da educação ambiental em uma escola do campo no município de Agudo-RS. Revista Formação, 25(44), $15-$ 33.

Oliveira, M. E. B. de, \& Gómez, J. R. M. (2014). A educação do campo no contexto do modelo de desenvolvimento rural no Brasil: o princípio educativo do trabalho como alternativa1, Revista Pegada, 15(1), 171-207.

Pereira, H. dos S., Kudo, S. A., \& Silva, S. C. P. da. (2018). Topofilia e valoração ambiental de fragmentos florestais urbanos em uma cidade amazônica. Ambiente \& Sociedade, 21, 2 -16 . 
Reigada, C., \& Tozoni-Reis, M. F. C. (2004). Educação ambiental para crianças no ambiente urbano: uma proposta de pesquisa-ação. Ciência \& Educação, 10(2), 149-159.

Rizzo, G. (1997). Jogos inteligentes: a construção do raciocínio na escola natural (3a ed.). Rio de Janeiro: didática e científica.

Santos, M. (2018). Educação do Campo no Plano Nacional de Educação: tensões entre a garantia e a negação do direito à educação. Ensaio: Aval. Pol. Públ. Educ, 26(98), 185212.

Santana, I., Rezende, C., \& Silva, J. (2019) Conscientização e preservação de um rio: proposta pedagógica através de um jogo didático. Revista Eletrônica Científica Ensino Interdisciplinar, 5(14), 405-420.

Siqueira, I. de J., \& Antunes, A. M. (2013). Jogo de trilha "lixo urbano": educação ambiental para sensibilização da comunidade escolar. Ensino, Saúde e Ambiente, 3(6), 185-201.

Souza, A. P. G. de, Reis, H. A., Monteiro, I. G., Rodrigues, D. C. G. de A., Soares, R. A. R., \& Pereira, R. F. P. (2015). Proposta de um jogo lúdico sobre a temática resíduos sólidos: uma ameaça a biodiversidade e conservação do Rio Bocaina. Cadernos Unifoa, $1(29), 15-20$.

Sousa, J. G. de, \& Pinho, M. J. de. (2017). Interdisciplinaridade e transdisciplinaridade como fundamentos na ação pedagógica: aproximações teórico-conceituais. Signos, 38(2), 93 110.

Tristão, M. (2004). Saberes e fazeres da educação ambiental no cotidiano escolar. Revista Brasileira de Educação Ambiental, 1, 47-55.

Tuan, Y. (1980). Topofilia: um estudo da percepção, atitudes e valores do Meio Ambiente. São Paulo: Difel.

Vygotsky, L. L. (1988). Linguagem, desenvolvimento e aprendizagem. São Paulo: Ícone.

\section{AGRADECIMENTOS}

Ao Núcleo de Estudos em Agroecologia do IFMA Campus São Luís Monte Castelo. 